\title{
Microtubule-Associated Protein 2
}

National Cancer Institute

\section{Source}

National Cancer Institute. Microtubule-Associated Protein 2. NCI Thesaurus. Code C125216.

Microtubule-associated protein 2 (1827 aa, $200 \mathrm{kDa})$ is encoded by the human MAP2 gene. This protein may play a role in microtubule stability. 